\title{
CONF-941144--95
}

\section{ELEVATED TEMPERATURE STATIC FATIGUE OF A NICALON FIBER-REINFORCED SiC COMPOSITE}

\author{
HUA-TAY LIN, PAUL F. BECHER, AND PETER F. TORTORELLI
}

Metals and Ceramics Division, Oak Ridge National Laboratory, Oak Ridge, TN 37831-6068

\begin{abstract}
Static fatigue tests of a Nicalon fiber-reinforced $\mathrm{SiC}$ matrix composite were conducted in four-point bending over a temperature range of $425^{\circ}$ to $1150^{\circ} \mathrm{C}$ in air at selected stress levels. The composite consisted of a Nicalon cloth with a $0.3 \mu \mathrm{m}$ graphite interfacial coating and a Forced Chemical Vapor Infiltration (FCVI) SiC matrix composite; samples were tested with or without a final protective $\mathrm{SiC}$ seal coat. The results indicated that the fatigue life of the Nicalon$\mathrm{SiC}$ composite decreased with an increase in either applied stresses or test temperatures. However, the composite exhibited a fatigue limit of $\sim 100 \mathrm{MPa}$ at temperatures $\leq 950^{\circ} \mathrm{C}$ which decreased to $\sim 70 \mathrm{MPa}$ at $1150^{\circ} \mathrm{C}$. Both electron microscopy and thermogravimetric studies suggested that the lifetime of the composites was dictated by the oxidation of graphite interfacial layer at temperatures $\leq 700^{\circ} \mathrm{C}$ and by oxidation of graphite coating accompanied by formation of silicate interfacial layer via oxidation of the Nicalon fiber (and the $\mathrm{SiC}$ matrix) at temperatures $\geq$ $950^{\circ} \mathrm{C}$. Use of a SiC seal coat effectively retarded the oxidation reactions and increased the lifetime by at least one order of magnitude at $425^{\circ} \mathrm{C}$. On the other hand, the $\mathrm{SiC}$ seal coat made little (if any) difference in fatigue life at $950^{\circ} \mathrm{C}$.
\end{abstract}

\section{INTRODUCTION}

Continuous fiber-reinforced ceramic composites (CFCCs), potential candidates for various structural applications at elevated temperatures, offer substantially improved damage tolerance over the monolithic ceramics. $\mathrm{SiC}$ fiber-reinforced $\mathrm{SiC}$ composite $(\mathrm{SiC} / \mathrm{SiC}$ ) is selected as a primary candidate for elevated temperature applications due to its attractive mechanical performance at room and elevated temperatures [1-7].

Often in $\mathrm{SiC} / \mathrm{SiC}$ composites, a graphitic fiber coating is èmployed to facilitate the interfacial debonding and fiber pullout and, thus, develop very high toughness and damage tolerance. Graphite is known to oxidize at temperatures above $400^{\circ} \mathrm{C}$ [8]; therefore, there is real concern over the mechanical performance and long-term reliability of $\mathrm{SiC} / \mathrm{SiC}$ composites at elevated temperatures. Indeed in the absence of an outer seal coat, exposure of a $\mathrm{SiC} / \mathrm{SiC}$ composite containing $\mathrm{a} \sim 0.36 \mu \mathrm{m}$ graphite fiber coating to an oxidizing environment at $950^{\circ} \mathrm{C}$ resulted in a substantial degradation in mechanical properties [9]. In this case, no stress was applied to test specimens during elevated temperature exposure to air. Degradation in fracture resistance and strength was observed and related to the oxidation of the graphite and the formation of $\mathrm{SiO}_{2}$ bond layer between the matrix and fiber. Such effects can also be enhanced by the application of a static stress during air exposure at $950^{\circ} \mathrm{C}[10]$. A separate study showed that the use of an external $\mathrm{SiC}$ seal coat could prevent or reduce such strength degradation when the air exposures at $1000^{\circ} \mathrm{C}$ were conducted in the absence of an applied stress [11].

In the present study the effect of applied flexural stress on the lifetime of a Nicalon fiberreinforced $\mathrm{SiC}$ composite at temperatures from $400^{\circ}$ to $1150^{\circ} \mathrm{C}$ in air was investigated. The experiment was designed to investigate the temperature range over which oxidation effects can alter the mechanical performance of a Nicalon fiber-SiC composite with a graphitic interfacial layer/fiber coating. The effect of a dense CVD SiC protective external seal coat on the static fatigue behavior was also evaluated.
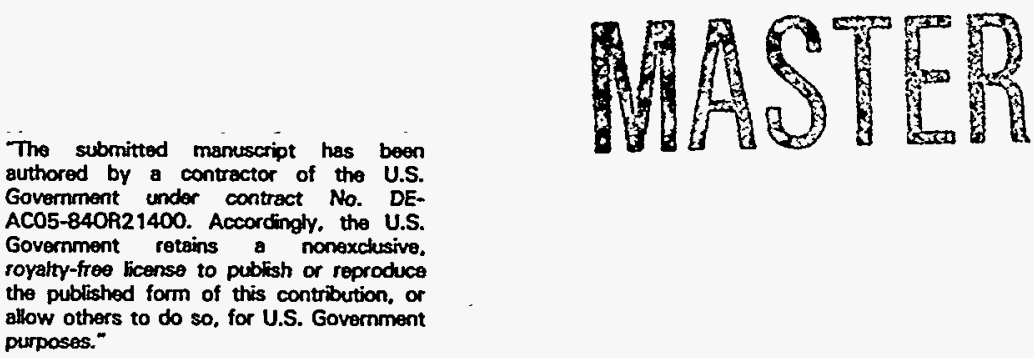


\section{DISCLAIMER}

Portions of this document may be illegible in electronic image products. Images are produced from the best available original document. 


\section{EXPERIMENTAL PROCEDURES}

Time to failure studies as a function of applied stress and temperature were conducted in air on bend bars machined from a large 254-mm diameter by $18-\mathrm{mm}$ thick SiC matrix composite disk. The composite, fabricated at Oak Ridge National Laboratory (ORNL), consisted of a Forced Chemical Vapor Infiltrated (FCVI) SiC matrix and $\sim 43 \%$ Nicalon fibers (Nippon Carbon Company, Tokyo, Japan) in the form of plain weave cloth with the cloth layers rotated $30^{\circ}$ between layers. The fiber in the Nicalon cloth had a $\sim 0.3 \mu \mathrm{m}$ graphite coating, which was deposited prior to infiltration of the SiC matrix, to facilitate interfacial debonding and pullout. Additional details for the fabrication procedures of this Nicalon-SiC composite can be found in Refs. 12-13. The bend bars, $3 \mathrm{~mm} \times 4 \mathrm{~mm} \times>50 \mathrm{~mm}$, were cut from disk so that the tensile surfaces were parallel to the plane of the cloth layers. A portion of the bars were seal-coated with CVD SiC following machining; the thickness of the CVD SiC seal coating was $\sim 40$ to $50 \mu \mathrm{m}$. The geometric densities (thus mechanical properties, i.e., elastic modulus and fracture strength) of the bend bars varied somewhat depending on their position with respect to the thickness and diameter of the SiC-Nicalon composite disk [14]. Care was thus taken to conduct tests on bend bars of the same density to ensure consistency of the measured lifetime.

The static fatigue in four point bending was conducted at temperatures from $425^{\circ}$ to $1150^{\circ} \mathrm{C}$ in air. The test fixtures were fabricated from sintered $\alpha$-SiC with inner and outer spans of 20 and $40 \mathrm{~mm}$, respectively. The test bars were held in the fixture with a small load $(<15$ $\mathrm{MPa}$ applied outer fiber tensile stress) and heated to the desired test temperature and allowed to equilibrate for 20 minutes prior to increasing applied stress to the selected level. The applied stress was then held constant until the bend bar failed; at that point sensors interrupted the furnace power supply circuit to allow the bend bars to cool quickly. In addition, oxidation experiments using thermogravimetric analysis (TGA) were performed on the composite to evaluate the oxidation kinetics at the selected temperatures. Optical and scanning electron microscopy (SEM) were used to characterize the high temperature fracture surfaces.

\section{RESULTS AND DISCUSSION}

Figure 1 shows the time to failure versus applied stress curves for the Nicalon fiber reinforced $\mathrm{SiC}$ composite with a $0.3 \mu \mathrm{m}$ graphite fiber coating but without a protective external $\mathrm{SiC}$ seal coat. The results at $950^{\circ} \mathrm{C}$ indicate that the Nicalon-SiC composite has a short lifetime $(<1 \mathrm{~h})$ at the applied stresses $>100 \mathrm{MPa}$. However at applied stresses $<100 \mathrm{MPa}$, failures of the composite appeared to be avoided (Fig. 1). For instance, the composite did not fracture at $950^{\circ} \mathrm{C}$ for test times of more than $1600 \mathrm{~h}$ when the applied stress was $\leq 100 \mathrm{MPa}$. A fatigue limit was also observed at $1150^{\circ} \mathrm{C}$ when the applied stress was lowered to $70 \mathrm{MPa}$, but the sample did exhibit a permanent curvature after long term tests. The results also indicate that both the fast fracture strengths and the lifetimes of the composite decrease with increase in temperature up to $1150^{\circ} \mathrm{C}$. The lifetime curves were simply displaced along the time axis as the test temperature decreased (Fig. 1). The lifetime of this Nicalon-SiC composite at temperatures below $950^{\circ} \mathrm{C}$ increased with decrease in test temperature or applied stress level. Lifetimes of $>10$ hours at applied stresses of $\geq 100 \mathrm{MPa}$ were only observed at temperatures $\leq 600^{\circ} \mathrm{C}$.

The specimens tested in the above case were without a protective SiC seal coating. Samples were next tested that had an external SiC seal coating of $\sim 40 \mu \mathrm{m}$ to protect the fiber ends exposed on the machined surfaces. Figure 2 shows the lifetime versus applied stress curves for coated and uncoated composite specimens at temperatures of $425^{\circ}$ and $950^{\circ} \mathrm{C}$ in air. Because the dense $\mathrm{SiC}$ in the seal coating is similar to that in the matrix, the onset of matrix (and coating) cracking of coated and uncoated samples should occur at the same applied stress levels. As a result, the coated specimens exhibit a lifetime curve at $950^{\circ} \mathrm{C}$ similar to that obtained for the uncoated specimens. Therefore at $950^{\circ} \mathrm{C}$, the seal coat does not provide any significant protective function; the lifetimes of the composite at $950^{\circ} \mathrm{C}$ at stress above the fatigue limit are still $\leq 1 \mathrm{~h}$. As seen in Fig. 2, the $\mathrm{SiC}$ seal coating was effective in retarding the oxidation effects at $425^{\circ} \mathrm{C}$ significantly increasing ( $>10$ times) the static fatigue life and lifetimes $>100 \mathrm{~h}$ could be reached.

SEM observation of the fracture surfaces tested at temperatures $\geq 950^{\circ} \mathrm{C}$ revealed a brittle 


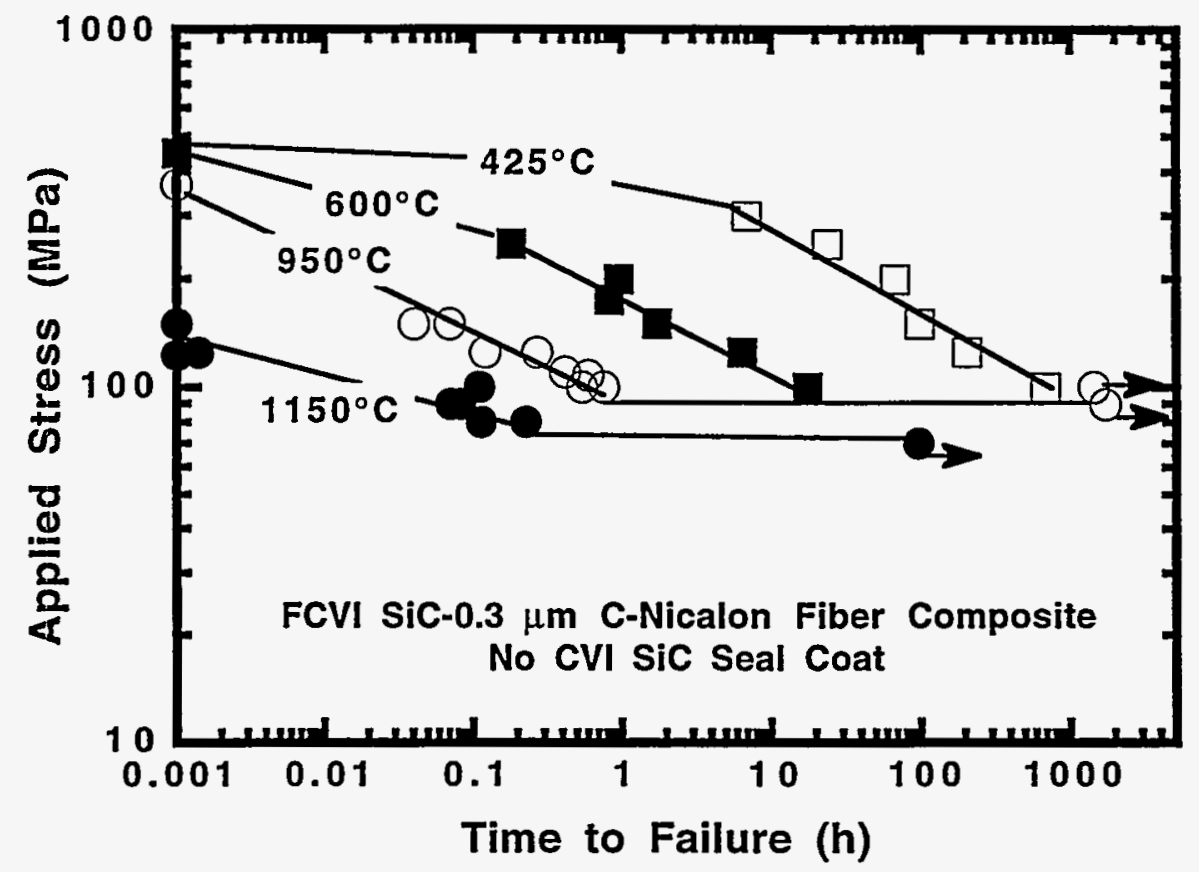

Figure 1. When subjected to applied stresses, the $\mathrm{SiC} / \mathrm{C} / \mathrm{Nicalon}$ composite exhibited stress-dependent lifetimes at applied stresses $>$ the proportional limit of $100 \mathrm{MPa}$. The lifetimes increased with decrease in test temperature and applied stress level.

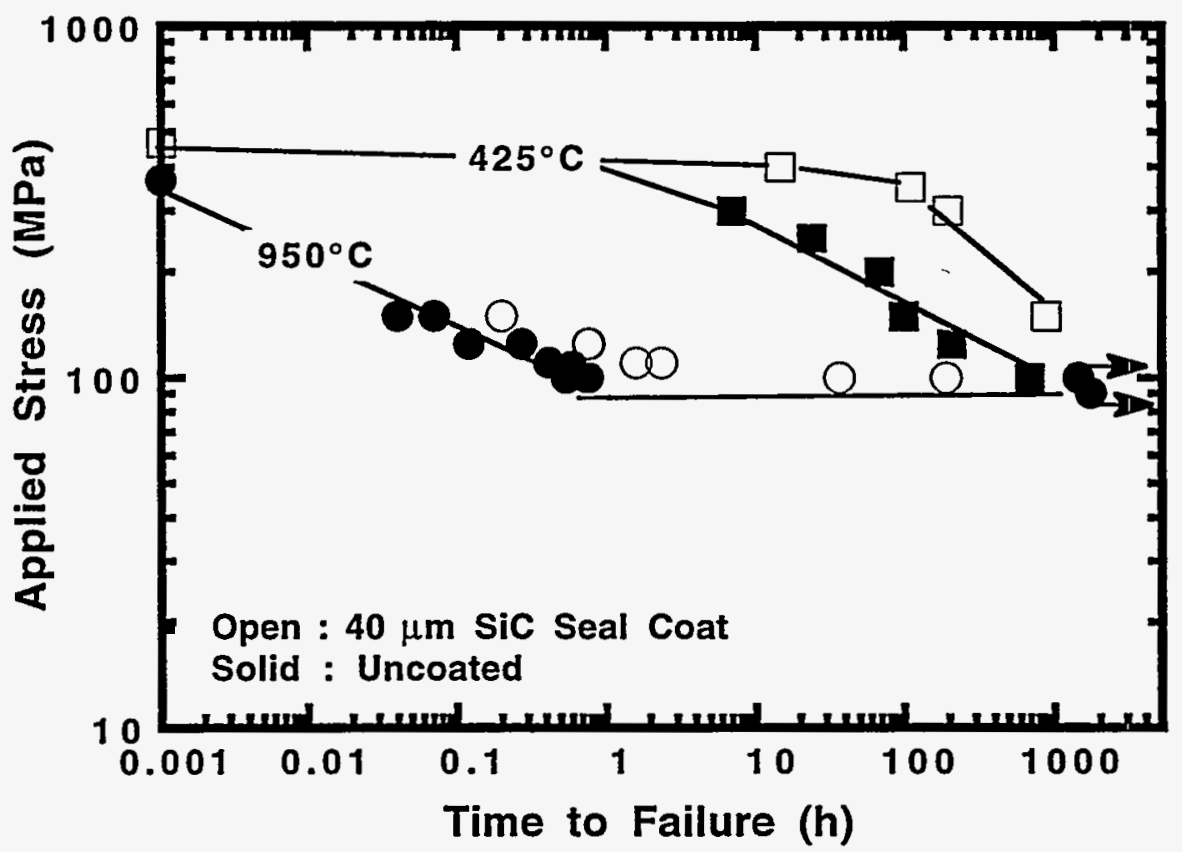

Figure 2. A $40 \mu \mathrm{m} \mathrm{SiC}$ seal coating is effective in extending the lifetimes of the composite at $425^{\circ} \mathrm{C}$, but has little effect on lifetimes at $950^{\circ} \mathrm{C}$ as compared with the results for uncoated specimens.

fracture surface near the tensile surface edge without any fiber pullout. Further examination of these regions show that the matrix-fiber interface is bridged by oxidation products that form an interfacial bond across. This is consistent with the TGA results [15] that reveal a rapid initial weight loss followed by monotonically increasing weight gain with time consistent with the 
oxidation of the graphite coating that diminishes as the silicate formation continues and seals the exposed interfaces. These processes result in increases in both the interfacial debonding stress and the interfacial shear stress eliminating fiber bridging and pullout [16].

At test temperatures $\leq 600^{\circ} \mathrm{C}$, fiber pullout was observed in tensile surface region of the fracture surface (Fig. 3a), and the surface area of fiber pullout increased with increase in applied stress and decrease in test temperature. The fiber pullouts near the tensile surface exhibited smooth fiber surfaces free of a coating; whereas fibers in regions $\sim 0.5-1 \mathrm{~mm}$ below the tensile surface and within the compressive subsurface exhibited the presence of residual graphite layer (Fig. 3b). At temperatures below $600^{\circ} \mathrm{C}$, the oxidation of the graphite should be the only operative degradation process as the oxidation of the CVI SiC and Nicalon fiber should be insignificant. Oxidation studies [17] indicate that the weight loss from the oxidation of graphite to $\mathrm{CO}$ and/or $\mathrm{CO}_{2}$ at both of $425^{\circ}$ and $600^{\circ} \mathrm{C}$ over long exposure times $(400 \mathrm{~h})$ occurs in the absence of surface sealing. In this case, the interfacial debond and shear stresses will be continuously reduced approaching zero $\mathrm{MPa}$ level with time [16]. This will result in negligible stress transfer from the matrix to the high strength fibers; thus the composite strength would continuously decrease with time.

\section{SUMMARY}

Static fatigue tests were conducted in four-point bending at temperatures from $425^{\circ}$ to $1150^{\circ} \mathrm{C}$ in air at selected applied stress levels on a Nicalon fiber-reinforced Forced Chemical Vapor Infiltration (FCVI) SiC composite with a $\sim 0.3 \mu \mathrm{m}$ graphite interfacial coating either with or without a protective external $\mathrm{SiC}$ seal coat. The results for samples without a seal coat showed that the fatigue life of the Nicalon-SiC composite decreased with increasing applied stress and/or test temperature. The composite exhibited a fatigue limit of $\sim 100 \mathrm{MPa}$ at temperatures $\leq 950^{\circ} \mathrm{C}$ but was reduced to $\sim 70 \mathrm{MPa}$ at $1150^{\circ} \mathrm{C}$. The lifetime of the Nicalon-SiC composites was dictated by the oxidation of graphite interfacial layer at low temperatures $\left(400^{\circ}\right.$ to $\left.700^{\circ} \mathrm{C}\right)$ and by both the oxidation of the graphite coating and formation of a silicate interfacial layer due to oxidation of the $\mathrm{SiC}$ matrix and the Nicalon fiber at temperatures $\geq 950^{\circ} \mathrm{C}$, consistent with the TGA results. The CVD SiC seal coat effectively retarded the oxidation reaction and, thus, increased the lifetime $>10$-fold at $425^{\circ} \mathrm{C}$. But it was not apparent that the SiC seal coat had any significant protective value at $950^{\circ} \mathrm{C}$.

\section{ACKNOWLEDGMENTS}

The authors thank Drs. M. K. Ferber and Chun-Hway Hsueh for reviewing the manuscript and R. A. Lowden for providing the FCVI SiC-Nicalon composites. Research is sponsored by the U.S. Department of Energy, Assistant Secretary for Energy, Efficiency and Renewable Energy, Office of Industrial Technologies, Energy Efficiency Division and Continuous Fiber Ceramic Composite Program, under contract DE-AC05-840R21400 with Martin Marietta Energy Systems, Inc.

\section{REFERENCES}

1. P. J. Lamicq, G. A. Bernhart, M. M. Dauchier, and J. G. Mace, Am. Ceram. Soc. Bull., 65 [2] 336-38 (1986).

2. M. Gomina and J. L. Chermant, pp. 8-1-8-18, in Proc. of AGARD Report 795 on "Introduction of Ceramics into Aerospace Structural Composites," North Atlantic Treaty Organization (1993).

3. S. Raghuraman, J. F. Stubbins, M. K. Ferber and A. A. Wereszczak, Ceram. Eng.. Sci. Proc., in press.

4. N. Frety and M. Boussuge, Comp. Sci. Technol., 37, 177-189 (1990) .

5. D. Singh and J. P. Singh, Ceram. Eng. Sci. Proc., 14 [9-10] 1153-64(1993). 


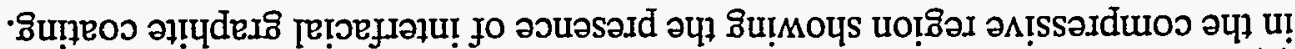

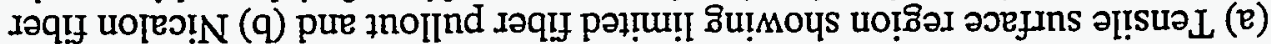

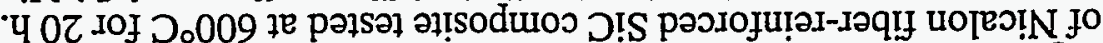

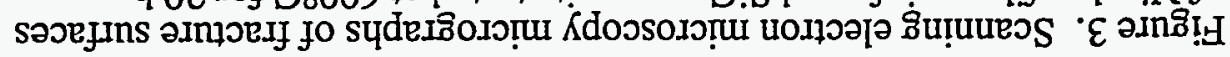
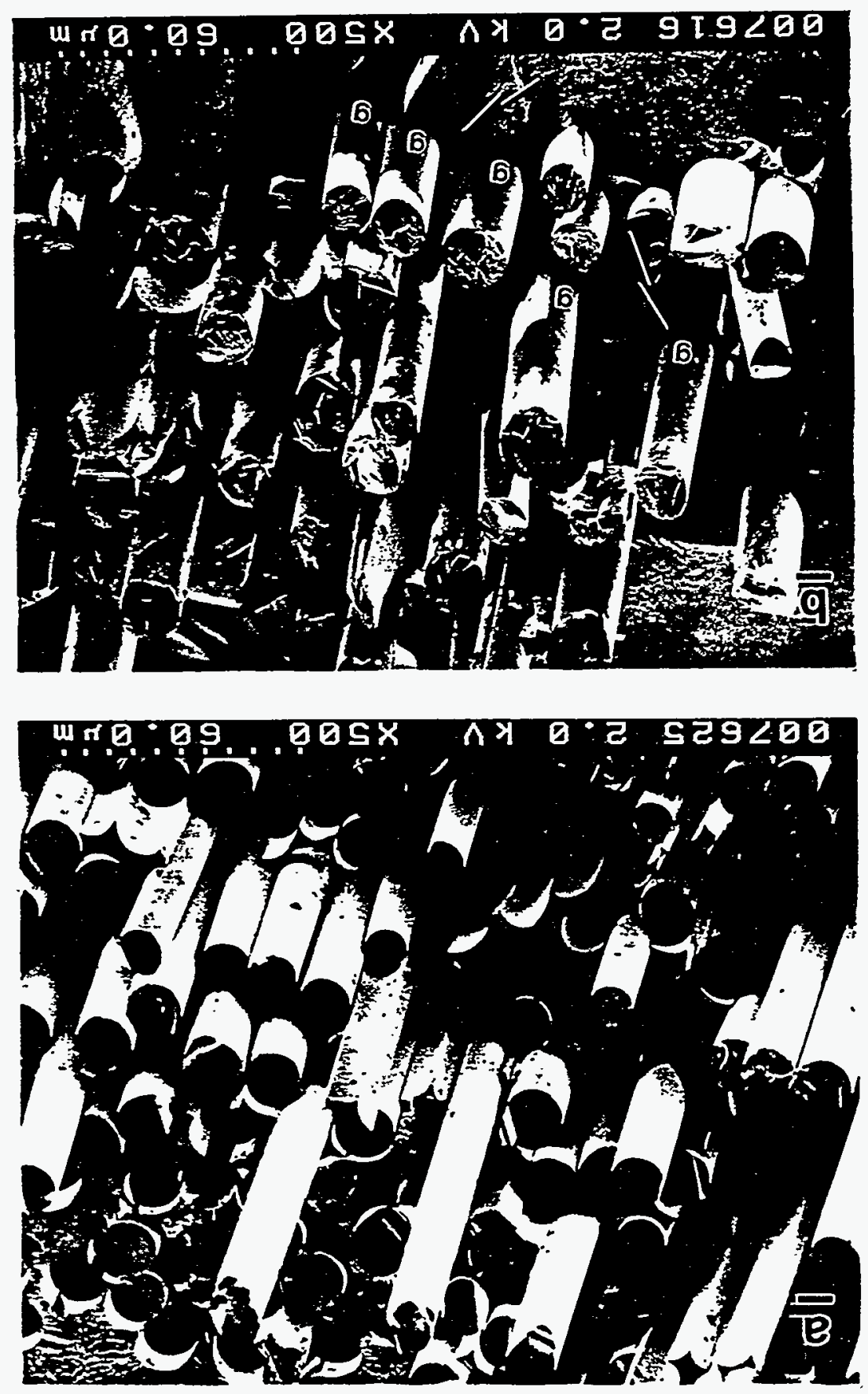
6. S. V. Nair and Y. L. Wang, Ceram. Eng. Sci. Proc., 13 [7-8] 433-41 (1992).

7. A. Chulya, J. Z. GyeKenyesi, and J. P. Gyekenyesi, Ceram. Eng. Sci. Proc., 13 [7-8] 42032 (1992).

8. K. S. Goto, K. H. Han, and G. R. St. Pierre, Trans. Iron and Steel Inst. Japan, 26, 597603 (1986).

9. P. F. Tortorelli, S. L. Riester, and R. A. Lowden, Ceram. Eng. Sci. Proc., 14 [1-2] 358-66 (1993).

10. S. Raghuraman, M. K. Ferber, J. F. Stubbins, and A. A. Wereszczak, Ceramic Matrix Composite Symposium, Am. Ceram. Soc., Westerville, $\mathrm{OH}$, in press.

11. R. A. Lowden and R. D. James, ORNL/TM-11893, J. F. Stubbins, Oak Ridge National Laboratory, Oak Ridge, TN (1991).

12. D. P. Stinton, A. J. Caputo, and R. A. Lowden, Am. Ceram. Soc. Bull., 65 [2] 347-50 (1986).

13. T. M. Besmann, B. W. Sheldon, R. A. Lowden, and D. P. Stinton, Science 253, 1104-9 (1991).

14. P. F. Becher and H. T. Lin, pp. 37-40, in Continuous Fiber Ceramic Composites Program Task 2 Bimonthly Progress Report for February-March 1994, Oak Ridge National Laboratory, Oak Ridge, TN (1994).

15. P. F. Tortorelli, J. R. Keiser, L. Restore, E. Lara-Curzio, pp. 64-66, in Continuous Fiber Ceramic Composites Program Task 2 Bimonthly Progress Report for April-may 1994, Oak Ridge National Laboratory, Oak Ridge, TN (1994).

16. Edgar Lara-Curzio, unpublished results.

17. P. F. Tortorelli, J. R. Keiser, L. Restore, E. Lara-Curzio, pp. 51-54, in Continuous Fiber Ceramic Composites Program Task 2 Bimonthly Progress Report for June-July 1994, Oak Ridge National Laboratory, Oak Ridge, TN (1994).

\section{DISCLAIMER}

This report was prepared as an account of work sponsored by an agency of the United States This report was prepared States Government nor any agency thereof, nor any of their Government. Neither the United States Government nor assumes any legal liability or responsiemployees, makes any warranty, express or implied, or assumes any legal lability, product, or bility for the accuracy, completeness, or usefulness of any ininge privately owned rights. Referprocess disclosed, or represents that its use would not infringe privately owe name, trademark, ence herein to any specific commercial product, process, or ser imply its endorsement, recommanufacturer, or otherwise does not necessarily constitute or imply its endersent The views mendation, or favoring by the United States Government or any agency theflect those of the and opinions of authors expressed herein do not

United States Government or any agency thereof. 